\title{
Yalta Conference and cerebrovascular disease
}

\section{La Conferencia de Yalta y la enfermedad cerebrovascular}

\author{
Amado Jiménez-Ruiz ${ }^{*}$ and Adriana Ruiz-Razura ${ }^{2}$ \\ ${ }^{1}$ Western University, Department of Neurology, Ontario, Canada; ${ }^{2}$ Benemérita Sociedad de Geografía y Estadística del Estado de Jalisco, University \\ Center of Art, Architecture and Design, Jalisco, Mexico
}

A clever person solves a problem. A wise person avoids it. Albert EINSTEIN

We read carefully the article titled "Head and Neck Cancer. Its impact on the history of mankind", by José Francisco Gallegos Hernández, published in Gaceta Médica de México number 2 of 2020. ${ }^{1}$ This historical review leaves the message that cancer can be curable at an early stage, and that prevention constitutes the best treatment. We believe this to be true for most diseases and by way of a sample, a photograph (Fig. 1).

In 1945, the Yalta Conference marked the end of World War II. A famous photograph during the meeting shows the victorious leaders of that huge conflagration. The United States, the United Kingdom and the Soviet Union were discussing the reorganization of Europe after the armed conflict. On the left, Winston Churchill, followed by Franklin D. Roosevelt and, at the end, Joseph Stalin; the three most powerful men on the planet at that moment. However, there were other similarities: all three died of cerebrovascular complications, including ischemia and cerebral hemorrhage, ${ }^{2-4}$ all three were smokers (in the photograph it can be seen that one holds a cigar and another one a cigarette), hypertensive and obese; all three represent the archetype of the patient with a disease that might have been prevented with risk factor adequate control. Surely, should these characters have survived their vascular conditions, history would

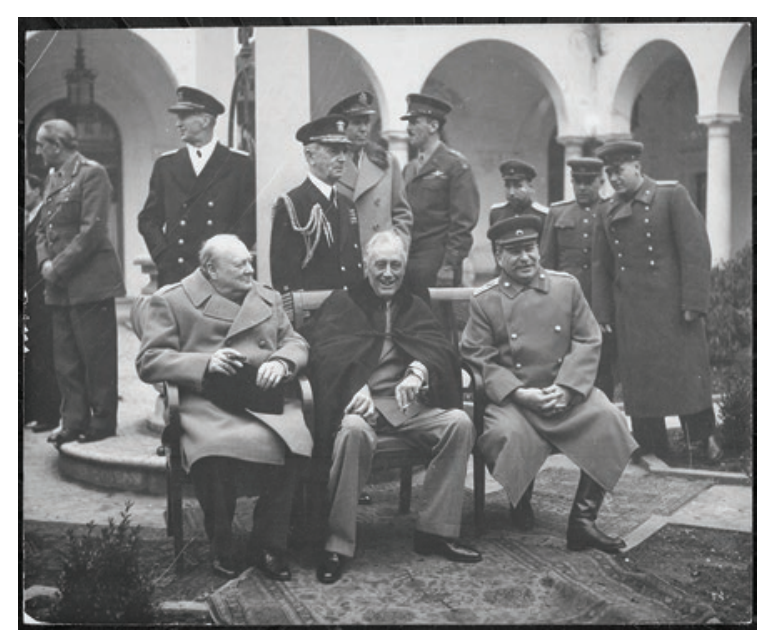

Figure 1. The Yalta Conference (source: public domain).

have been different. We agree with Gallegos Hernández that prevention continues to be a fundamental pillar of medical science and we should always consider it a priority.

\section{References}

1. Gallegos-Hernández JF. Cáncer de cabeza y cuello. Su impacto en la historia de la humanidad. Gac Med Mex. 2020;156:104-109.

2. Jones JM, Jones JL. Presidential stroke: United States presidents and cerebrovascular disease. CNS Spectr. 2006;11:674-678.

3. Ali R, Connolly ID, Li A, Choudhri OA, Pendharkar AV, Steinberg GK. The strokes that killed Churchill, Roosevelt, and Stalin. Neurosurg Focus. 2016;41:E7.

4. Barth RF, Brodsky SV, Ruzic M. What did Joseph Stalin really die of? A reappraisal of his illness, death, and autopsy findings. Cardiovasc Pathol Off J Soc Cardiovasc Pathol. 2019;40:55-58. 